\title{
HUBUNGAN PERSEPSI TENTANG PENYAKIT DENGAN KUALITAS HIDUP PADA PASIEN DIABETES MELITUS TIPE 2 DENGAN KOMPLIKASI DI RSUD ABDUL WAHAB SJAHRANIE SAMARINDA
}

\author{
THE ASSOCIATION BETWEEN ILLNESS PERCEPTION WITH \\ QUALITY OF LIFE IN TYPE 2 DIABETES MELLITUS PATIENT \\ WITH COMPLICATIONS IN ABDUL WAHAB SJAHRANIE \\ HOSPITAL SAMARINDA
}

\author{
Naili Rafi'ah", Dyah Aryani Perwitasari \\ Fakultas Farmasi, Universitas Ahmad Dahlan \\ Jl. Prof. Dr. Soepomo SH, Yogyakarta, Telp (0274) 379418 \\ *Penulis Korespondensi, e-mail : naili_rafiah@yahoo.com
}

\begin{abstract}
ABSTRAK
Diabetes mellitus tipe 2 (DMT2) terjadi karena adanya resistensi insulin dan gangguan sekresi insulin. Insidensi DMT2 mencapai 90-95\% dari penyakit diabetes mellitus secara umum. Adanya komplikasi yang menyertai DMT2 dapat membahayakan jiwa dan menurunkan kualitas hidup. Persepsi pasien tentang penyakit juga dapat berkontribusi terhadap kualitas hidup pasien. Oleh karena itu, penilaian terhadap persepsi dengan kualitas hidup pasien DMT2 dengan komplikasi sangat penting karena kualitas hidup yang menurun akibat persepsi tentang penyakit yang buruk dapat memperparah penyakit dan menyebabkan kematian. Untuk mengetahui hubungan persepsi pasien dengan kualitas hidup DMT2 dengan komplikasi yang dinilai dengan menggunakan kuesioner Short Form 36 (SF-36) dan Brief Illness Perceptions Questionnaire (B-IPQ). Penelitian ini menggunakan rancangan penelitian observasional analitik dengan pendekatan cross sectional, pengambilan data secara prospektif pada pasien DMT2 dengan komplikasi di RSUD Abdul Wahab Sjahranie Samarinda. Instrumen yang digunakan dalam penelitian adalah kuesioner SF-36 dan kuesioner persepsi B-IPQ. Pada penelitian ini dilakukan uji validasi pada kuesioner Sf-36. Analisis data dilakukan secara deskriptif dan menggunakan uji regresi linear multivariat. Hasil penelitian menunjukkan bahwa domain konsekuensi, durasi, identitas dan respon emosi pada kuesioner persepsi B-IPQ berpengaruh terhadap kualitas hidup pasien DMT2. Hasil tersebut didasarkan pada analisis regresi linear dengan metode stepwise yang menunjukkan bahwa terdapat hubungan signifikan antara domain persepsi tentang penyakit (B-IPQ) dengan domain kualitas hidup (SF-36) yaitu domain fungsi fisik $(p=0,014)$, keterbatasan peranan emosi $(p=0,002)$, keterbatasan peranan emosi ( $p=0,003)$, fatigue $(p=0,000)$, kesehatan mental $(p=0,000)$, fungsi sosial $(p=$ $0,002)$, nyeri $(p=0,008)$ dan kesehatan umum $(p=0,000)$. Ada hubungan bermakna antara persepsi tentang penyakit dengan kualitas hidup pada pasien DMT2 dengan komplikasi. Penelitian ini dapat menjadi dasar kepada seluruh tenaga kesehatan agar dapat meningkatkan kualitas pelayanan kesehatan, intervensi klinis serta pemahaman
\end{abstract}


pasien terkait penyakit DMT2 dengan komplikasi sehingga dapat meningkatkan kualitas hidup pasien.

Kata kunci : diabetes mellitus tipe 2, persepsi tentang penyakit, kualitas hidup

\begin{abstract}
T2DM is mainly occurred due to insulin secretion problem. The prevalence of T2DM is estimate at approximately 90-95\% of total diabetes mellitus cases in general. The complications may put patient's life in danger as well as decrease the quality of life. Patient's perception about disease also may contribute to quality of life. Therefore, the assesment against illness perceptions with quality of life of TDM2 patients with complication is importance as reduced quality of life, as result of a poor illness perception, may worsen the illness and even lead to fatality. The aim of this study is to understand association between both perceptions with quality of life of TDM2 patients with complication which are assessed by using SF-36 and B-IPQ. This study used analytical observational design with cross sectional approach, the data are collected prospectively from the T2DM patient with complications at Abdul Wahab Sjahranie Hospital in Samarinda. It was also using two questionnaire as the research instrument, they are SF-36 and B-IPQ. The SF-36 questionnaire was validated in this study. The data are analyzed descriptively and used multivariate linear regression. The results of research suggest that the consequences, timeline, identity, and emotional representative from questionnaire perception BIPQ influence quality of life in TDM2 patients. The result obtained from linear regression analysis with a stepwise method show that there was a significant association between domain Illness Perception (B-IPQ) with domain Quality of Life $(S F-36)$ those are physical function $(p=0.014)$, role limitations due to phisycal health $(p=0.002)$, role limitations due to emotional problems $(p=0.003)$, fatigue $(p=0.000)$, mental health $(p=0.000)$, social function $(p=0.002)$, pain $(p=$ $0.008)$ and general health $(p=0.000)$. There is a significant correlation between illness perception with quality of life in TDM2 patiens with complications. Based on these results, therefore the improvement in healthcare, clinical intervention, and adequate information of TDM2 for the patients provided by health professionals are expected to improve the quality of life of the patients.
\end{abstract}

Keywords : Type-2 Diabetes Mellitus, Illness Perception, and Quality of Life 


\section{PENDAHULUAN}

Diabates Militus adalah suatu sekumpulan gangguan metabolik yang dicirikan dengan hiperglikemia (kenaikan kadar gula darah diatas normal), karena adanya kelainan sekresi insulin, kerja insulin atau kedua-duanya (ADA, 2010 ; RISKESDAS, 2013). Diabetes tipe 2 dikenal dengan non-insulin-dependent atau adult-onset diabetes, disebabkan penggunaan insulin yang kurang efektif oleh tubuh. DM yang diderita oleh pasien 90\% merupakan diabetes tipe 2 (Infodatin, 2014).

Pada tahun 2012, dikatakan bahwa prevalensi angka kejadian DM di dunia adalah sebanyak 371 juta jiwa (IDF, 2013), dimana proporsi untuk kejadian DMT2 adalah sebesar 95\% dari dari populasi dunia yang menderita DM dan hanya 5\% dari jumlah tersebut yang menderita DM Tipe 1 (DMT1) (CDC, 2012). Jika DM tidak ditangani dengan baik, maka berbagai komplikasi dapat muncul. Komplikasi yang ditimbulkan dapat bersifat akut dan kronis, yang dapat membahayakan jiwa, menurunkan kualitas hidup dan mempengaruhi usia harapan hidup pasien (Black et al., 1993 ; Yusra, 2010).

Kualitas hidup penderita DM adalah gambaran perasaan puas dan bahagia akan kehidupan secara umum, khususnya hidup dengan diabetes (Yudiyanto et al.,, 2008). Salah satu luaran dari suatu terapi penyakit adalah untuk meningkatkan kualitas hidup pasien, untuk itu WHO memunculkan konsep kualitas hidup ini. Permasalahan kualitas hidup perlu dipertimbangkan karena luaran terapi tidak hanya sekedar mempertimbangkan data laboratorium dan hasil pemeriksaan fisik pasien setelah mendapat pengobatan saja (Perwitasari, 2014).

Persepsi tentang penyakit merupakan pendekatan yang digunakan secara luas dalam psikologi kesehatan, salah satunya digunakan untuk menjelaskan perilaku dan cara mengatasi DMT2 (Weinman \& Petrie, 1997; Anonim, 2014). Persepsi atau pemahaman tentang kesehatan dipengaruhi oleh bagaimana penderita percaya terhadap kemampuannya menjalani pengobatan, kehidupan, psikososial, pendidikan yang dimiliki serta dukungan keluarga (Pricahyo, 2012). Kegagalan dalam mengelola aspek psikologi dapat berpengaruh buruk terhadap kualitas hidup pasien DMT2 dan persepsi pasien terkait penyakit berkontribusi terhadap kualitas hidup pasien (Donald et al., 2012). Oleh karena itu, penilaian terhadap persepsi dengan kualitas hidup pasien DMT2 
dengan komplikasi sangat penting karena kualitas hidup yang menurun akibat persepsi tentang penyakit yang buruk dapat memperparah penyakit dan menyebabkan kematian.

Instrumen yang direkomendasikan untuk menilai kualitas hidup pasien dapat menggunakan Short Form 36-item Health Survey (SF-36) dan persepsi pasien tentang penyakit dapat digunakan Brief Illness Perceptions Questionnaire (B-IPQ) (Perwitasari et al., 2011 ; Broadbent et al., 2006). Tujuan dari penelitian ini adalah untuk mengetahui hubungan antara persepsi pasien tentang penyakit dengan kualitas hidup pasien DMT2 dengan komplikasi.

\section{METODE PENELITIAN}

Penelitian ini menggunakan rancangan penelitian observasional analitik dengan pendekatan cross sectional. Penelitian ini dilakukan di Poliklinik Penyakit Dalam RSUD A. W. Sjahranie Samarinda pada akhir bulan April-Juli 2016.

Subjek penelitian yang digunakan dalam penelitian ini adalah pasien DMT 2 yang diterapi rawat jalan di RSUD A. W. Sjahranie Samarinda pada akhir bulan April-Juli 2016, yang memenuhi kriteria inklusi dan secara suka rela berpartisipasi atau ikut dalam penelitian ini. Adapun kriteria inklusi pada penelitian ini yaitu pasien dengan diagnosa DM tipe 2 dengan komplikasi berdasarkan international code diagnosis (ICD) E11.00, E11.21, E11.22, E11.29, E11.311, E11.319, E11.40, E11.41, E11.42, E11.43, E11.44, E11.49, E11.620, E11.621, E11.622, E11.628, E11.65, E11.69, pasien yang menderita DMT2 dengan komplikasi lebih dari 3 bulan, pasien dengan umur 15-65 tahun, pasien bersedia mengikuti penelitian dengan menandatangani informed consent, dan pasien yang tidak buta huruf. Kriteria eksklusi penelitian adalah pasien dalam kondisi hamil, pasien yang menjalani rawat inap, dan pasien yang mengisi kuesioner dengan tidak jelas I asal-asalan (pengisian kuesioner tidak lengkap atau kuesioner diisi langsung tanpa membaca pertanyaan yang tercantum).

Instrumen yang digunakan pada penelitian ini yaitu kuesioner Short Form-36 (SF36) yang mencakup 8 aspek penilaian, diantaranya fungsi fisik, keterbatasan peranan fisik, keterbatasan peranan emosi, fatigue/kelelahan, kesehatan mental, fungsi sosial, nyeri dan kesehatan umum. Untuk persepsi tentang penyakit digunakan Brief-Illness 
Perception Questionnaire (B-IPQ) terdiri dari 9 pertanyaan yang mencakup 8 aspek penilaian dan 1 pertanyaan terbuka. Delapan aspek penilaian tersebut diantaranya konsekuensi, durasi, kontrol pribadi, kontrol pengobatan, identitas, kekhawatiran, pemahaman dan respon emosi.

Data yang dikumpulkan pada penelitian ini meliputi data demografi pasien, data kuesioner SF-36 dan data kuesiner B-IPQ. Dari data kuesioner tersebut kemudian dilakukan perhitungan skor kualitas hidup dan persepsi. Kemudian, dilakukan validasi instrument SF-36. Untuk melakukan analisis hubungan antara persepsi dan kualitas hidup dilakukan analisis multivariat regresi linear. Ada dua tahapan yang dilakukan pada saat melakukan analisis uji regresi linear, yaitu : seleksi kandidat (pemilihan variabel dengan $p$ value $<0,25$ dilakukan dengan uji Spearman correlate) dan pemodelan multivariate (memasukkan variabel dengan $p$ value $<0,25$ untuk dilakukan uji regresi linear berganda).

\section{Validasi Kuesioner SF-36}

Kuesioner SF-36 merupakan kuesioner generik (umum) yang dapat dipergunakan secara luas untuk menilai kualitas hidup pasien pada berbagai macam penyakit maupun usia. Terdapat 36 pertanyaan singkat yang mencakup 8 domain didalamnya (Harmaini, 2006 ; Perwitasari, 2012). Uji validasi pada penelitian ini dilakukan pada 30 data dari hasil skoring kuesioner SF-36 pada pasien DMT2 dengan komplikasi. Dari total 36 pertanyaan SF-36, hanya 35 pertanyaan saja yang divalidasi. Pertanyaan yang tidak dimasukkan pada uji validasi adalah pertanyaan nomer 2 yang berbunyi "Dibandingkan satu tahun yang lalu, bagaimanakah kondisi kesehatan anda saat ini?". Hal ini dikarenakan pertanyaan nomer 2 tersebut tidak mewakili domain manapun dari total 8 domain yang terdapat dalam kuesioner SF-36. Berikut uji validasi dipaparkan lebih lanjut.

\section{Uji Validasi}

Uji validasi dilakukan untuk menunjukkan tingkat kevalidan atau kesahihan suatu instrumen. Suatu kuesioner dikatakan valid jika pertanyaan kuesioner mampu untuk mengungkapkan sesuatu yang akan diukur oleh kuesioner tersebut (Arikunto, 2006 ; 
Ghozali, 2011). Pada penelitian ini didapatkan hasil uji validasi untuk semua pertanyaan kuesioner SF-36 dinyatakan valid secara konvergen dan diskriminan $(\mathrm{r}=0,632-0,993)$, kecuali pertanyaan nomer 35 pada domain kesehatan umum.

Pada penelitian ini untuk domain kesehatan umum terdapat butir pertanyaan yang tidak valid, yaitu pada butir nomer 35. Pertanyaan nomer 35 ini berbunyi "sesuaikah atau tidak sesuaikah pernyataan berikut ini dengan kondisi anda? saya berharap kesehatan saya akan memburuk". Seluruh responden pada penelitian ini memilih jawaban "pasti salah", sehingga jawaban seluruh responden bernilai konstan. Hasil skor yang konstan tersebut tidak dapat diperhitungkan, sehingga output data nilai $\mathrm{p}$ dan $\mathrm{r}$ tidak muncul pada butir pertanyaan nomer 35, karena tidak adanya perbedaan jawaban yang diberikan, maka variabel yang dikorelasikan benar-benar tidak memiliki hubungan yang signifikan, sehingga output data dapat diasumsikan bernilai 0,000 artinya tidak ada hubungan bermakna antar variabel. Hal tersebut dijelaskan dalam penelitian Perwitasari et al., (2011) dan Lee et al., (2005) yang menyebutkan bahwa > 90\% responden memiliki jawaban yang sama untuk beberapa item pertanyaan pada SF-36, sehingga menyebabkan lemahnya korelasi yang terjadi antara butir pertanyaan dan domain, akibatnya validitas konvergen tidak terpenuhi.

Uji validasi pada penelitian ini menghasilkan 34 butir pertanyaan yang valid dan 1 butir yang tidak valid, namun item pertanyaan yang valid dari domain tersebut dapat mewakili dalam menilai kualitas hidup. Dari uji validasi disimpulkan kuesioner SF-36 mampu menilai kualitas hidup pasien DMT2.

\section{Uji Reliabilitas}

Reliabilitas adalah salah satu uji yang digunakan untuk menunjukkan suatu instrument tersebut telah reliable untuk digunakan. Reliable disini artinya dapat dipercaya atau diandalkan (Arikunto, 2006). Reliabilitas dikatakan reliable jika jawaban seseorang terhadap pertanyaan konsisten atau stabil dari waktu kewaktu (Riyanto, 2009). Suatu variabel dikatakan reliable jika memberikan nilai Cronbach's Alpha > 0,70 dan nilai Cronbach's Alpha > r tabel (Ghozali, 2011).

Hasil uji reliabilitas pada penelitian ini didapatkan hasil yang baik pada keseluruhan item pertanyaan yang mewakili 8 domain (Cronbach's Alpha 0,766-0,983 ; 
Cronbach's Alpha $\geq 0,7)$. Hasil tersebut menunjukkan bahwa kuesioner SF-36 dapat dipercaya atau diandalkan (Reliable).

\section{Uji Validitas Known-Group}

Hasil uji validitas Known-Group menunjukkan tidak adanya perbedaan bermakna antara jenis kelamin, usia, tingkat pendidikan dan pekerjaan terhadap kualitas hidup (p $>0,05)$. Hasil tersebut menunjukkan bahwa kuesioner SF-36 dinyatakan baik untuk menilai kualitas hidup.

\section{HASIL DAN PEMBAHASAN}

Pada penelitian ini, terdapat 81 pasien yang masuk ke dalam kriteria inklusi penelitian. Berdasarkan Tabel I, diperoleh sebanyak 32 orang laki-laki (39\%) dan 49 orang (61\%) perempuan, dengan distribusi usia yaitu 28 pasien $(35 \%)$ berusia kurang dari 50 tahun dan 53 pasien (65\%) berusia 50 tahun keatas.

Gambaran kualitas hidup dan persepsi

Pada penelitian ini, kualitas hidup dan persepsi pasien DMT2 di RSUD A. W. Sjahranie Samarinda digambarkan secara deskriptif dengan menampilkan nilai rata-rata $($ mean $) \pm$ standar deviasi (SD) yang diuji dengan analisis univariat. Gambaran tersebut dapat dilihat pada Tabel II dan Tabel III.

Berdasarkan Tabel II didapatkan hasil rerata nilai kualitas hidup yang paling tinggi terdapat pada domain fungsi sosial $(92,59 \pm 17,65)$ dan yang terendah terdapat pada domain keterbatasan peranan fisik $(41,36 \pm 47,46)$. Nilai seluruh domain kualitas hidup yang didapatkan rata-rata diatas nilai normatif yaitu 50, hasil ini sesuai dengan penelitian Sahar et al., (2016), kecuali skor keterbatasan peranan fisik. Rendahnya skor keterbatasan peranan fisik (kurang dari nilai nomatif 50) diakibatkan karena adanya perubahan psikologis, fisiologis dan mental, sehingga kebanyakan responden menjadi tidak siap ketika harus membatasi aktivitas mereka sehari-hari (Rohmah et al., 2012).

Berdasarkan Tabel III , didapatkan hasil rerata nilai persepsi tentang penyakit yang paling tinggi terdapat pada domain kontrol pengobatan $(8,35 \pm 1,93)$ dan yang terendah terdapat pada domain respon emosi $(3,75 \pm 2,40)$. Pada pertanyaan terbuka dalam 
kuesioner B-IPQ tentang penyebab penyakit DMT2 didapatkan data deskriptif tentang 3 penyebab utama secara berturut-turut yaitu, faktor genetik $(64,2 \%)$, pola makan $(60,5 \%)$ dan kurang olahraga (40,7\%), hasil ini tidak berbeda dengan penelitian Oktarina (2014) yang menunjukkan bahwa penyebab utama penyakit diabetes adalah pola makan dan pola hidup.

Tabel I. Data demografi pasien DMT2 dengan komplikasi

\begin{tabular}{|c|c|}
\hline Karakteristik $(n=81)$ & n (\%) \\
\hline $\begin{array}{l}\text { Jenis Kelamin } \\
\text { Laki-laki } \\
\text { Perempuan }\end{array}$ & $\begin{array}{l}32(39) \\
4961)\end{array}$ \\
\hline $\begin{array}{l}\text { Usia } \\
<50 \text { tahun } \\
\geq 50 \text { tahun }\end{array}$ & $\begin{array}{l}28(35) \\
53(65)\end{array}$ \\
\hline $\begin{array}{l}\text { Status } \\
\text { Single* } \\
\text { Menikah } \\
\text { Pendidikan } \\
\text { Pendidikan rendah* } \\
\text { Pendidikan tinggi* }\end{array}$ & $\begin{array}{l}9(11) \\
72(89) \\
42(52) \\
39(48)\end{array}$ \\
\hline $\begin{array}{l}\text { Pekerjaan } \\
\text { Tidak bekerja* } \\
\text { Bekerja* } \\
\text { Penghasilan } \\
\text { Pendapatan rendah* } \\
\text { Pendapatan tinggi* }\end{array}$ & $\begin{array}{l}53(65) \\
28(35) \\
48(59) \\
33(41)\end{array}$ \\
\hline $\begin{array}{l}\text { Durasi Penyakit } \\
<5 \text { tahun } \\
\geq 5 \text { tahun }\end{array}$ & $\begin{array}{l}28(35) \\
53(65)\end{array}$ \\
\hline $\begin{array}{l}\text { Terapi } \\
\text { Monoterapi } \\
\text { Kombinasi } \\
\text { Komplikasi Penvakit }\end{array}$ & $\begin{array}{l}31(38) \\
50(62)\end{array}$ \\
\hline $\begin{array}{l}\text { Makrovaskular } \\
\text { Mikrovaskular } \\
\text { Mikrovaskular dan Makrovaskular }\end{array}$ & $\begin{array}{l}40(49) \\
25(31) \\
16(20)\end{array}$ \\
\hline
\end{tabular}

* Keterangan : Status single (belum menikah, duda atau janda), pendidikan rendah (tidak sekolah, tamat SD, atau tamat SMP), pendidikan tinggi (tamat SMA, diploma atau sarjana), tidak bekerja (pengangguran, ibu rumah tangga atau pensiunan), bekerja (PNS, buruh/petani, pegawai swasta atau wiraswasta), pendapatan rendah (tidak berpenghasilan atau dibawah standar UMR Kota Samarinda), pendapatan tinggi (penghasilan diatas standar UMR). 
Tabel II. Distribusi rerata nilai kualitas hidup pasien DMT2 dengan komplikasi

\begin{tabular}{lc}
\hline Domain & Mean \pm SD \\
\hline Fungsi fisik & $75,15 \pm 25,45$ \\
Keterbatasan peranan fisik & $41,36 \pm 47,46$ \\
Keterbatasan peranan emosi & $85,19 \pm 34,56$ \\
Fatigue & $81,42 \pm 13,14$ \\
Kesehatan mental & $90,52 \pm 7,71$ \\
Fungsi sosial & $92,59 \pm 17,65$ \\
Nyeri & $88,30 \pm 19,79$ \\
Kesehatan umum & $50,56 \pm 15,45$ \\
\hline
\end{tabular}

Tabel III. Distribusi rerata nilai persepsi pasien DMT2 dengan komplikasi

\begin{tabular}{lc}
\hline \multicolumn{1}{c}{ Domain } & Mean \pm SD \\
\hline Konsekuensi & $5,35 \pm 2,69$ \\
Durasi & $8,09 \pm 1,81$ \\
Kontrol pribadi & $7,20 \pm 1,87$ \\
Kontrol pengobatan & $8,35 \pm 1,93$ \\
Identitas & $4,70 \pm 2,09$ \\
Kekhawatiran & $5,11 \pm 2,59$ \\
Pemahaman & $7,84 \pm 1,45$ \\
Respon emosi & $3,75 \pm 2,40$ \\
\hline
\end{tabular}

Hubungan persepsi terhadap penyakit dengan kualitas hidup pasien DMT2 dengan komplikasi

Pada penelitian ini, untuk mengetahui hubungan antara persepsi tentang penyakit terhadap kualitas hidup pasien DMT2 dengan komplikasi digunakan analisis multivariat. Analisis multivariat yang digunakan adalah dengan uji regresi linear berganda karena variabel dependen berskala numerik. Tahapan pada uji ini meliputi seleksi kandidat dan pemodelan multivariat.

\section{Seleksi Kandidat}

Pemilihan variabel pada analisis multivariat ini dilakukan dengan uji Spearman correlate / korelasi Spearman (pemilihan uji ini berdasarkan pada hasil analisis normalitas data yang menunjukkan hasil sebaran data yang tidak normal $p<0,05)$. Uji korelasi Spearman akan menunjukkan variabel dengan nilai $p<0,25$, yang akan dianalisis menggunakan regresi linear berganda. 
Berdasarkan analisis uji korelasi Spearman hasil analisis menunjukkan adanya hubungan bermakna $(p<0,25)$ antara item BIPQ dengan domain dari kuesioner SF-36. Hampir seluruh domain B-IPQ memberikan pengaruh terhadap kualitas hidup. Hasil analisis dapat dilihat pada Tabel IV.

Tabel IV. Uji korelasi Spearman B-IPQ terhadap kualitas hidup (SF-36)

\begin{tabular}{lcccccccc}
\hline Item B-IPQ & \multicolumn{7}{c}{ Domain SF 36 } \\
\hline & FF & PF & PE & F & KM & FS & N & KU \\
\hline Konsekuensi & $0,001^{*}$ & $0,006^{*}$ & $0,036^{*}$ & $0,001^{*}$ & $0,000^{*}$ & $0,008^{*}$ & 0,343 & $0,000^{*}$ \\
Durasi & 0,864 & 0,815 & $0,131^{*}$ & $0,050^{*}$ & $0,194^{*}$ & 0,343 & $0,082^{*}$ & 0,337 \\
Kontrol Pribadi & $0,078^{*}$ & 0,447 & 0,492 & $0,013^{*}$ & $0,018^{*}$ & $0,087^{*}$ & 0,673 & $0,204^{*}$ \\
Kontrol Pengobatan & $0,056^{*}$ & 0,755 & $0,071^{*}$ & $0,031^{*}$ & $0,016^{*}$ & $0,060^{*}$ & $0,133^{*}$ & $0,022^{*}$ \\
Identitas & $0,034^{*}$ & 0,297 & $0,011^{*}$ & $0,030^{*}$ & $0,067^{*}$ & $0,002^{*}$ & $0,030^{*}$ & $0,064^{*}$ \\
Kekhawatiran & $0,006^{*}$ & $0,028^{*}$ & $0,052^{*}$ & $0,024^{*}$ & $0,000^{*}$ & $0,003^{*}$ & $0,087^{*}$ & $0,032^{*}$ \\
Pemahaman & 0,460 & 0,897 & 0,430 & $0,125^{*}$ & 0,327 & 0,839 & 0,696 & $0,105^{*}$ \\
Respon Emosi & $0,000^{*}$ & $0,001^{*}$ & $0,011^{*}$ & $0,001^{*}$ & $0,000^{*}$ & $0,004^{*}$ & $0,183^{*}$ & $0,000^{*}$ \\
\hline
\end{tabular}

Keterangan : FF (fungsi fisik); PF (keterbatasan peranan fisik); PE (keterbatasan peranan emosi); F

(fatigue); KM (kesehatan mental); FS (fungsi sosial); N (nyeri); KU (kesehatan umum). $* P<0,25$

Hasil analisis di atas telah sejalan dengan penelitian sebelumnya yang dilakukan oleh Yaragchi et al., (2012), Benyamini et al., (2012) dan Long (2013) yang menyatakan bahwa domain B-IPQ memiliki pengaruh terhadap kualitas hidup. DMT2 merupakan salah satu penyakit kronis yang memerlukan pengobatan seumur hidup. Hal inilah yang menyebabkan beberapa pasien mulai membangun persepsi tentang penyakit yang dideritanya. Banyak faktor yang menyebabkan terjadinya penurunan kualitas hidup, salah satunya adalah persepsi negatif yang dibangun ketika seseorang tidak dapat mengelola penyakit yang dideritanya. Sebaliknya pasien yang beranggapan bahwa kondisinya baik-baik saja cenderung mempunyai kualitas hidup yang baik, sehingga dimensi dari B-IPQ akan cenderung lebih positif. 
Pemodelan Multivariat

Domain B-IPQ yang belum memenuhi syarat $p$ value $>0,25$ dimasukkan ke dalam pemodelan multivariat yang selanjutnya akan dilakukan uji regresi linear berganda. Hasil uji multivariat ini akan menentukan domain persepsi apa saja yang benar-benar mempengaruhi kualitas hidup. Analisa regresi linear pada penelitian ini disajikan pada Tabel V.

Tabel V. Uji regresi linear berganda B-IPQ terhadap kualitas hidup (kuesioner SF-36)

\begin{tabular}{|c|c|c|c|c|c|}
\hline \multirow{2}{*}{$\begin{array}{c}\text { Domain } \\
\text { Kualitas hidup (SF-36) }\end{array}$} & \multirow[t]{2}{*}{ Item B-IPQ } & \multicolumn{2}{|c|}{$\begin{array}{c}\text { Model Summary } \\
\mathbf{R}^{2}\end{array}$} & \multirow{2}{*}{$\begin{array}{l}\text { Coefficients } \\
\text { Persamaan Garis }\end{array}$} & \multirow[t]{2}{*}{$\begin{array}{l}\text { ANOVA } \\
\text { Sig. }\end{array}$} \\
\hline & & & & & \\
\hline Fungsi Fisik & Konsekuensi (K) & 0,375 & 0,074 & $\mathrm{QOL}=88,92-2.58 \mathrm{~K}$ & 0,014 \\
\hline $\begin{array}{l}\text { Keterbatasan peranan } \\
\text { fisik }\end{array}$ & Respon emosi (RE) & 0,375 & 0,114 & $\mathrm{QOL}=66,37-6,67 \mathrm{RE}$ & 0,002 \\
\hline $\begin{array}{l}\text { Keterbatasan peranan } \\
\text { emosi }\end{array}$ & Identitas (I) & 0,282 & 0,107 & $\mathrm{QOL}=110,65-5,41 \mathrm{I}$ & 0,003 \\
\hline \multirow[t]{2}{*}{ Fatigue } & Konsekuensi (K) & 0,359 & 0,214 & $\mathrm{QOL}=76,95-2,05 \mathrm{~K}+1,90 \mathrm{D}$ & 0,000 \\
\hline & Durasi (D) & 0,218 & & & \\
\hline \multirow[t]{2}{*}{ Kesehatan mental } & Respon emosi (RE) & 0,466 & 0,259 & $\mathrm{QOL}=86,08-1,43 \mathrm{RE}+1,21 \mathrm{D}$ & 0,000 \\
\hline & Durasi (D) & 0,146 & & & \\
\hline Fungsi sosial & Identitas (I) & 0,344 & 0,116 & $\mathrm{QOL}=106,11-2,87 \mathrm{I}$ & 0,002 \\
\hline Nyeri & Identitas (I) & 0,242 & 0,086 & $\mathrm{QOL}=101,36-2,78 \mathrm{I}$ & 0,008 \\
\hline Kesehatan umum & Konsekuensi (K) & 0,519 & 0,269 & $\mathrm{QOL}=66,45-2,97 \mathrm{~K}$ & 0,000 \\
\hline
\end{tabular}

Berdasarkan Tabel $\mathrm{V}$, analisis regresi linear dengan metode stepwise menunjukkan bahwa terdapat hubungan signifikan antara domain persepsi pada seluruh domain SF-36 yaitu domain fungsi fisik $(p=0,014)$, keterbatasan peranan fisik ( $p=$ $0,002)$, keterbatasan peranan emosi $(p=0,003)$, fatigue $(p=0,000)$, kesehatan mental $(p=$ $0,000)$, fungsi sosial $(p=0,002)$, nyeri $(p=0,008)$ dan kesehatan umum $(p=0,000)$. Hasil uji regresi linear menunjukkan bahwa domain persepsi seperti konsekuensi, durasi, identitas dan respon emosi mempunyai hubungan terhadap kualitas hidup.

Konsekuensi dikaitkan dengan kualitas fisik yang buruk dan meningkatknya beban hidup karena penyakit, sehingga pasien akan mempunyai kecemasan yang besar terkait konsekuensi buruk penyakit yang akan diterimanya. Keyakinan terhadap munculnya konsekuensi penyakit yang buruk ini akan berdampak secara langsung terhadap kualitas hidup pasien (Aalto et al., 2005 dan Long, 2013). Sejalan dengan hasil 
penelitian ini domain konsekuensi mempunyai nilai rendah artinya pasien mempunyai persepsi negatif bahwa penyakit DMT2 dengan komplikasi mempunyai konsekuensi yang cukup serius, sehingga hal ini akan berimbas terhadap penurunan kualitas hidup.

Adanya hubungan bermakna pada domain durasi telah sejalan dengan penelitian Yaraghchi et al., (2012) yang menyebutkan durasi memiliki hubungan bermakna dengan kualitas hidup. Penyakit kronis seperti DMT2 akan berlangsung seumur hidup karena penyakit ini tidak dapat disembuhkan, namun dapat dikontrol. Kemampuan pasien dalam menerima hal tersebut akan menyebabkan meningkatnya kualitas hidup, namun menurut Hagger dan Orbell (2003) kebanyakan pasien dengan penyakit kronis akan cepat berputus asa dan tidak menerima durasi penyakit yang akan berlangsung seumur hidup ini. Hal inilah yang akan membuat pasien menjadi stres dan membuat penyakit menjadi parah. Semakin parah penyakit akan membuat kondisi kesehatan baik fisik maupun mental pasien menjadi buruk, akibatnya kualitas hidup pasien pun akan menurun. Sejalan dengan hasil penelitian ini domain durasi penyakit bernilai tinggi artinya pasien telah paham bahwa penyakit DMT2 dengan komplikasi tidak dapat disembuhkan, sehingga dengan pemahaman pasien tersebut dapat meningkatkan kualitas hidupnya.

Sejalan dengan penelitian yang dilakukan oleh Yaraghchi et al., (2012) identitas memiliki hubungan yang bermakna terhadap kualitas hidup. Identitas merupakan gambaran tentang penyakit yang berkaitan dengan gejala-gejala penyakit yang muncul. Kurangnya kontrol diri terhadap penyakit akan menyebabkan terjadinya keparahan penyakit. Semakin parah penyakit akan menimbulkan gejala - gejala penyakit yang sering dirasakan oleh pasien, gejala penyakit yang sering timbul tersebut akan mengakibatkna menurunnya kualitas hidup pasien (Aalto et al., 2005 dan Wahl et al., 2013). Pada penelitian ini identitas bernilai rendah artinya pasien sering merasakan gejala-gejala penyakit yang berimbas pada penurunan kualitas hidup.

Adanya hubungan bermakna antara respon emosi dan kualitas hidup ini sejalan dengan penelitian yang dilakukan oleh Yaraghchi et al., (2012), Wahl et al., (2013) dan Long (2013) menyebutkan bahwa terdapat hubungan bermakna antara persepsi dan kualitas hidup. Pasien dengan penyakit kronis lebih cenderung memiliki emosi yang tidak stabil (lebih mudah marah, cemas, dan takut). Respon emosi yang negatif yang 
ditimbulkan inilah yang berdampak terjadinya kualitas hidup yang buruk (Wahl et al., 2013 dan Long, 2013). Hasil penelitian ini menunjukkan nilai respon emosi yang negatif (bernilai rendah) sehingga pasien cenderung merasa lebih emosional dengan penyakitnya yang menyebabkan penurunan kualitas hidup.

\section{KESIMPULAN}

Ada hubungan bermakna antara persepsi tentang penyakit dengan kualitas hidup pada pasien DMT2 dengan komplikasi. Penelitian ini dapat menjadi dasar kepada seluruh tenaga kesehatan agar dapat meningkatkan kualitas pelayanan kesehatan, intervensi klinis serta pemahaman pasien terkait penyakit DMT2 dengan komplikasi sehingga dapat meningkatkan kualitas hidup pasien.

\section{UCAPAN TERIMA KASIH}

Penelitian ini tidak terlepas dari peran serta beberapa pihak yang telah membantu jalannya penelitian ini. Termasuk diantaranya Fakultas Farmasi, Universitas Ahmad Dahlan, Yogyakarta dan RSUD Abdul Wahab Sjahranie Samarinda yang telah memfasilitasi penelitian ini, serta responden yang bersedia ikut berperan dalam penelitian ini.

\section{DAFTAR PUSTAKA}

Aalto, A. M., Heijmans, M., Weinman, J., Aro, A. R., 2005, Illness Perceptions in Coronary Heart Disease. Sociodemographic, Illness-Related, and Pyschosocial Correlates. J Psychosom Res, 58 : 393-402.

ADA, 2010, Position statement: Standards of Medical Care in Diabetes 2010. Diab Care. 2010;33(Suppl. 1).

Anonim, 2014, http://www.uib.no/ipq/ diakses tanggal 3 Januari 2014.

Arikunto S, 2006, Prosedur Penelitian Suatu Pendekatan Praktik, Ed Revisi VI. Penerbit PT Rineka Cipta : Jakarta.

Black, J. M., Matassarin-Jacobs, E., Luckmann, J., 1993. Luckmann and Sorensen's Medical-surgical Nursing : A Psychophysiologic Approach. Philadelphia: W. B. Saunders Co. 
Benyamini, Y., Goner-Shilo, D., Lazarov, A., 2012, Illness Perception and Quality of Life in Patients with Contact Dermatitis. Contact Dermatitis, 67(4) : 193-199.

Broadbent, E., Petrie, K.J., Main, J., dan Weinman, J., 2006, The Brief Illness Perception Questionnaire (BIPQ), Journal of Psychosomatic Research, 60, 631-637.

CDC, 2012, Number (in Millions) of Persons with Diabetes Aged 35 Years or Older with Self-Reported Heart Disease or Stroke, United States, 1997-2010 www.CDC.gov (2 Februari 2016).

Oktarina, D. R. L., 2014. Hubungan Antara Persepsi Penyakit dengan Manajemen Diri Pada Penderita Diabetes yang Memiliki Riwayat Keturunan. Jurnal Psikologi Klinis dan Kesehatan Mental, (3) 1: 25-32.

Donald, M., Dower, J., Ware, R., Mukandi B., Parekh, S., dan Bain, C., 2012, Living with Diabetes: Rationale, Study Design and Baseline Characteristics for An Australian Prospective Cohort Study, BMC Public Health, 12(8): 1-10.

Ghozali, I., 2011, Aplikasi analisis multivariate dengan program SPSS. Semarang : Badan penerbit Universitas Diponegoro, Hal : 48-52

IDF, 2013, IDF diabetes atlas. 6th edition. International Diabetes Federation.

Infodatin, 2014, Infodatin Pusat data dan Informasi Kementrian Kesehatan RI. Kementrian Kesehatan RI : Jakarta Selatan

Hagger, M., Orbell, S., 2003, A Meta-Analytic Review of The Common-Sense model of Illness Representations, Psychol Health, 18:141-184

Harmaini, F., 2006. Uji Keandalan dan Kesahihahn Formulir European Quality of Life5 Dimensions (EQ-5D) untuk mengukur Kualitas Hidup Terkait Kesehatan pada Usia Lanjut di RSUPNCM Indonesia, Tesis, Universitas Indonesia : Jakarta

Lee, E. H., Chun, M., Wang, H. J., Lim, H. Y., Choi, J. H., 2005, Multidimensional constructs of the EORTC Quality of life Qustionnaire (QLQ-C30) in Korean cancer patients with heterogenous diagnoses. Cancer Res Treat ;37:148-56

Long, R. N., 2013, Illness Perceptions, Quality of Life, and Psychological Functioning in Patients with Chronic Obstructive Pulmonary Disease,Thesis, The Ohio State University : Ohio

Perwitasari, D. A., Atthobari, J., Dwiprahasto, I., Hakimi, M., Gelderblom, H., Putter, H., Nortier, J. W. R., Guchelaar, H. J., Kaptein, A. A., 2011. Translation and validation of EORTC QLQ-C30 into Indonesian version for cancer patients in Indonesia. Jpn J Clin Oncol ; 41(4)519-529. 
Perwitasari, D. A., 2012, Development The Validation of Indonesian Version of SF-36 Questionnaire In Cancer Disease, Indones J. Pharm, 23(4) : 248-253.

Perwitasari, D A., 2014. Buku Ajar Monitoring Terapi Obat. Universitas Ahmad Dahlan : Yogyakarta : 8-9.

Pricahyo, H.D., 2012, Perbedaan Persepsi Pasien Laki-Laki Dan Tentang Kepatuhan Diet Diabetes Mellitus Di Ruang Mawar B Rsud Dr. Harjono Ponorogo, Karya Tulis Ilmiah, Prodi DII Keperawatan, Fakultas Ilmu Kesehatan Universitas Muhammadiyah Ponorogo : Ponorogo.

RISKESDAS, 2013, Riset Kesehatan Dasar, Badan Penelitian dan Pengembangan Kesehatan Kementrian Kesehatan RI.

Riyanto, A., 2009, Aplikasi metodologi penelitian kesehatan, Nuha Medika : Yogyakarta

Rohmah, A. I. N., Purwaningsih, Bariyah, K., 2012, Kualitas HidupLanjut Usia, Jurnal Keperawatan, 3 (2) : 120-132

Sahar, A. K., 2016, The Health Related Quality of Life in Normal and Obese Children. Pediatric Journal Asosiation, 64, 53-60.

Wahl, A. K, Robinson, H. S., Langeland, E., Larsen, M. H., Krogstad, A. L., and Moum, T., 2013, Clinical Characteristics Associated with Illness Perception in Psoriasis, Acta Derm Venereol, 93

Weinman, J., \& Petrie, K.J., 1997, Illness Perceptions: A New Paradigm for Psychosomatics?, Journal of Psychosomatic Research, 42(2): 113-116.

Yudianto, K., Rizmadewi, H., Maryati, I., 2008. Kualitas hidup penderita diabetes mellitus di Rumah Sakit Umum Daerah Cianjur, Universitas Padjajaran : Bandung, 10(18).

Yaraghchi, A., Rezaei, O., Mandegar, M. H., Bagherian, R., 2012, The Relationship between Illness Perception and Quality of Live in Iranian Patients with Coronary Artery Bypass Graft. Procedia - Social and Behavioral Science, 46 : 3329-3334.

Yusra, A., 2010. Hubungan antara dukungan keluarga dengan kualitas hidup pasien diabetes melitus tipe 2 di poliklinik penyakit dalam rumah sakit umum pusat Fatmawati Jakarta, Tesis, Fakultas Kedokteran Universitas Indonesia : Jakarta. 
